\title{
Influence of annealing process on microstructure and mechanical properties of C-Mn dual phase steel
}

\author{
M. Šbek ${ }^{1,2 *}$, P. Horňak ${ }^{2}$, S. Longauer², P. Zimovčák ${ }^{3}$, P. Záhumenský ${ }^{3}$ \\ ${ }^{1}$ Institute of Materials Research, Slovak Academy of Sciences, Watsonova 47, 04200 Košice, Slovak Republic \\ ${ }^{2}$ Technical University of Košice, Faculty of Metallurgy, Department of Materials Science, Košice, Slovak Republic \\ ${ }^{3}$ U. S. Steel Košice, s. r. o., Vstupný areál U. S. Steel, 04454 Košice, Slovak Republic
}

Received 24 April 2014, received in revised form 3 March 2015, accepted 3 March 2015

\begin{abstract}
The paper deals with the influence of annealing parameters on the evolution of microstructure and mechanical properties of a dual phase steel. Simulation of annealing regimes by thermo-mechanical simulator Gleeble was conducted. The dual phase steel was annealed in laboratory conditions in accordance with three specified annealing cycles: into intercritical region $\left(780^{\circ} \mathrm{C}\right.$, into austenite region $\left(920^{\circ} \mathrm{C}\right)$ and into austenite region $\left(920^{\circ} \mathrm{C}\right)$ by subsequently cooling into intercritical region $\left(780^{\circ} \mathrm{C}\right)$ with the hold at the temperature of $495^{\circ} \mathrm{C}$. Dwell time at $495^{\circ} \mathrm{C}$ simulates submerging of steel sheet into zinc bath. The obtained microstructure consists of three phases: ferritic matrix, martensite, and martensite/bainite grains. To identify the microstructure, transmission electron microscopy (TEM) and nanoindentation experiments were performed.
\end{abstract}

K e y w or d s: dual phase steel, annealing simulation, microstructure evolution, transmission electron microscopy observations, nanoindentation method

\section{Introduction}

Dual phase steel grades (hard martensite embedded in a soft ferrite matrix) offer attractive properties, such as continuous yielding, high work hardening rate, good uniform elongation and relatively high formability, which are of considerable interest for applications in the automotive industry [1-4].

The performance of cold rolled DP steel grades depends mainly on their chemical composition such as an alloy content of each phase and microstructural parameters such as the phase volume fraction and distribution, etc. The reasonable alloy composition design for DP steel grades can obtain required mechanical properties at a low cost. A few researchers have studied the effect of chemical composition, especially the micro-alloying elements and the volume fraction of composite phases (retained austenite, ferrite, martensite, bainite, etc.) on the mechanical properties of DP steel grades [5-7]. On the other hand, the thermo-mechanical processing conditions, involving hot rolling, cold rolling and es- pecially annealing result in the final microstructure $[8,9]$.

Commercial cold rolled DP steel grades are preferably produced by continuous annealing process in the intercritical (ferrite $(\alpha)+$ austenite $(\gamma)$ ) zone so as to obtain the satisfying sheet properties, such as a good surface and optimum homogeneous properties all over the sheet. The typically continuous annealing process has the stages of heating, soaking, slow cooling, rapid cooling, and over ageing. Modification of the chemical composition and parameters of continuous annealing, especially the temperature, has a pronounced influence on the microstructure development and thereby also on the properties of steel sheets [10-12].

The study was focused on the influence of the modified alloying (three times higher Cr content) and its impact on the microstructure evolution and the mechanical properties of a dual phase steel. Three different annealing regimes were studied (into intercritical region, into region of austenite and the combined annealing regime), whereas the influence of the higher $\mathrm{Cr}$ content on $\gamma \rightarrow \alpha$ transformation and also on the

*Corresponding author: tel.: +421557922448; fax: +421557922408; e-mail address: $\underline{\text { msebek@imr.saske.sk }}$ 


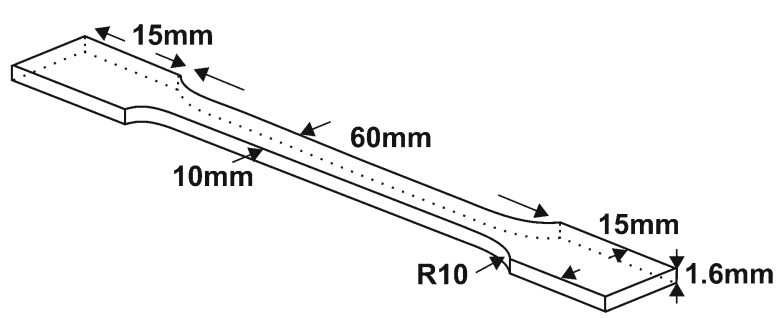

Fig. 1. Tensile strength sample dimensions.

creation of final microstructure and obtained mechanical properties, was investigated.

\section{Material and experimental procedure}

The experimental material was produced in a laboratory resistance furnace in an inert argon atmosphere. After that, the material was hot rolled in laboratory conditions, and then cold rolled with the final reduction of $70 \%$ followed. The chemical composition of the studied material is shown in Table 1 . To obtain the required properties, three times higher amount of $\mathrm{Cr}$ was used, whereas the Mo content was reduced to the minimum level.

Simulation of annealing regimes was done by the thermo-mechanical simulator Gleeble by using specimens presented in Fig. 1. After that, the tensile test related to the EN ISO 6892-1:2009 B standard was performed. Three annealing regimes were chosen. The first annealing cycle consisted of heating into inter- critical region $\left(780^{\circ} \mathrm{C}\right)$ (a), the second cycle consisted of heating into austenite region $\left(920^{\circ} \mathrm{C}\right)(\mathrm{b})$, and the third cycle consisted of heating into austenite region $\left(920^{\circ} \mathrm{C}\right)$ and subsequent cooling into intercritical region $\left(780^{\circ} \mathrm{C}\right)(\mathrm{c})$, as is showed in Fig. 2. The dwell time at $495^{\circ} \mathrm{C}$ simulated the input of a steel sheet into the Zn bath. For calculation of transformation temperatures of the intercritical region $A_{\mathrm{c} 1}$ and $A_{\mathrm{c} 3}$, Eqs. (1) and (2) were used [8]:

$$
\begin{gathered}
A_{\mathrm{c} 1}=723-10.7 \mathrm{Mn}-16.9 \mathrm{Ni}+29.1 \mathrm{Si}+16.9 \mathrm{Cr}+ \\
290 \mathrm{As}+6.8 \mathrm{~W}
\end{gathered}
$$

$$
\begin{gathered}
A_{\mathrm{c} 3}=910-203 \mathrm{C}^{1 / 2}-15.2 \mathrm{Ni}+44.7 \mathrm{Si}+10.4 \mathrm{~V}+ \\
31.5 \mathrm{Mo}+13.1 \mathrm{~W}-(30 \mathrm{Mn}+11 \mathrm{Cr}+20 \mathrm{Cu}-700 \mathrm{P}- \\
400 \mathrm{Al}-120 \mathrm{As}-400 \mathrm{Ti}) .
\end{gathered}
$$

The microstructure of a dual phase steel was documented by the light microscopy and scanning electron microscopy. To obtain a colour contrast, two etchants were used, first Nital and then Klemm. The grain boundaries were shown up well when Nital etchant was used. The grain bodies were contrasted by the Klemm colour etching. The colour etching resulted in a favourable contrast of different phases. The ferrite grains were in brown or blue tones; the martensite was brown and the austenite phase was white [13]. For SEM observations, only Nital as an etchant was used.

To identify the individual phases in the steel microstructure, the transmission electron microscopy observations were performed for the first and third annealing regimes. The discs were electro-polished us-

Table 1. Chemical composition of DP steel (wt.\%)

\begin{tabular}{cccccccc}
\hline $\mathrm{C}$ & $\mathrm{Mn}$ & $\mathrm{Cr}+\mathrm{Mo}$ & $\mathrm{P}$ & $\mathrm{S}$ & $\mathrm{Si}$ & $\mathrm{Al}_{\text {total }}$ & $\mathrm{V}$ \\
\hline 0.1 & 1.9 & 1 & 0.02 & 0.005 & 0.8 & $\leq 2.00$ & 0.002 \\
\hline
\end{tabular}

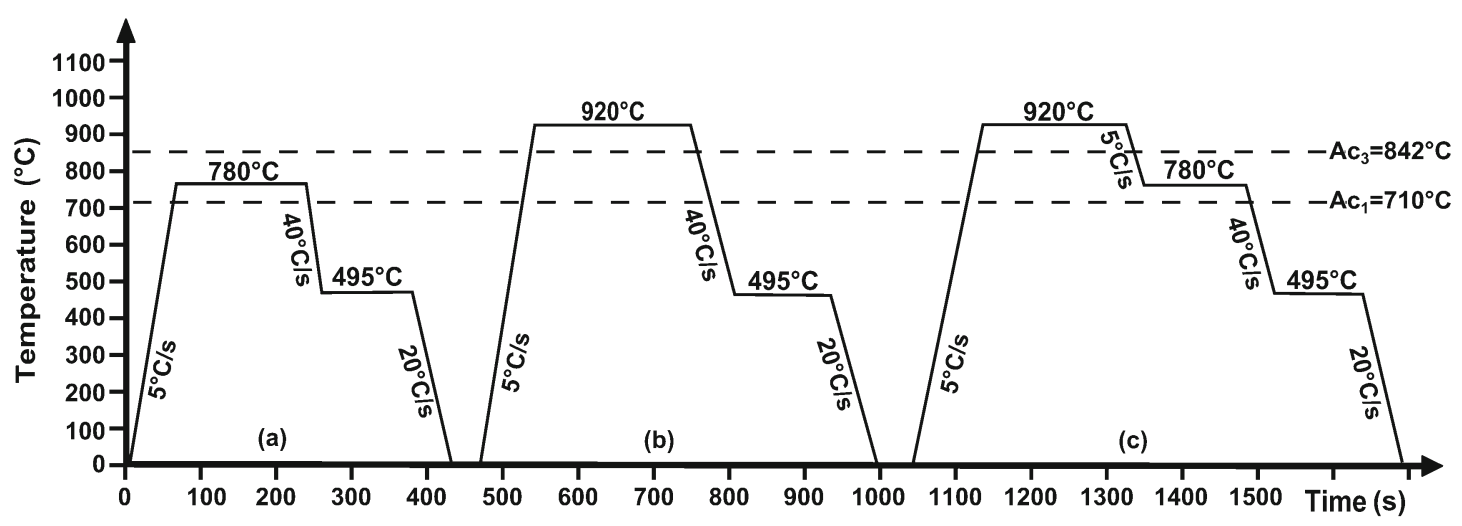

Fig. 2. Annealing regimes of DP steels. 

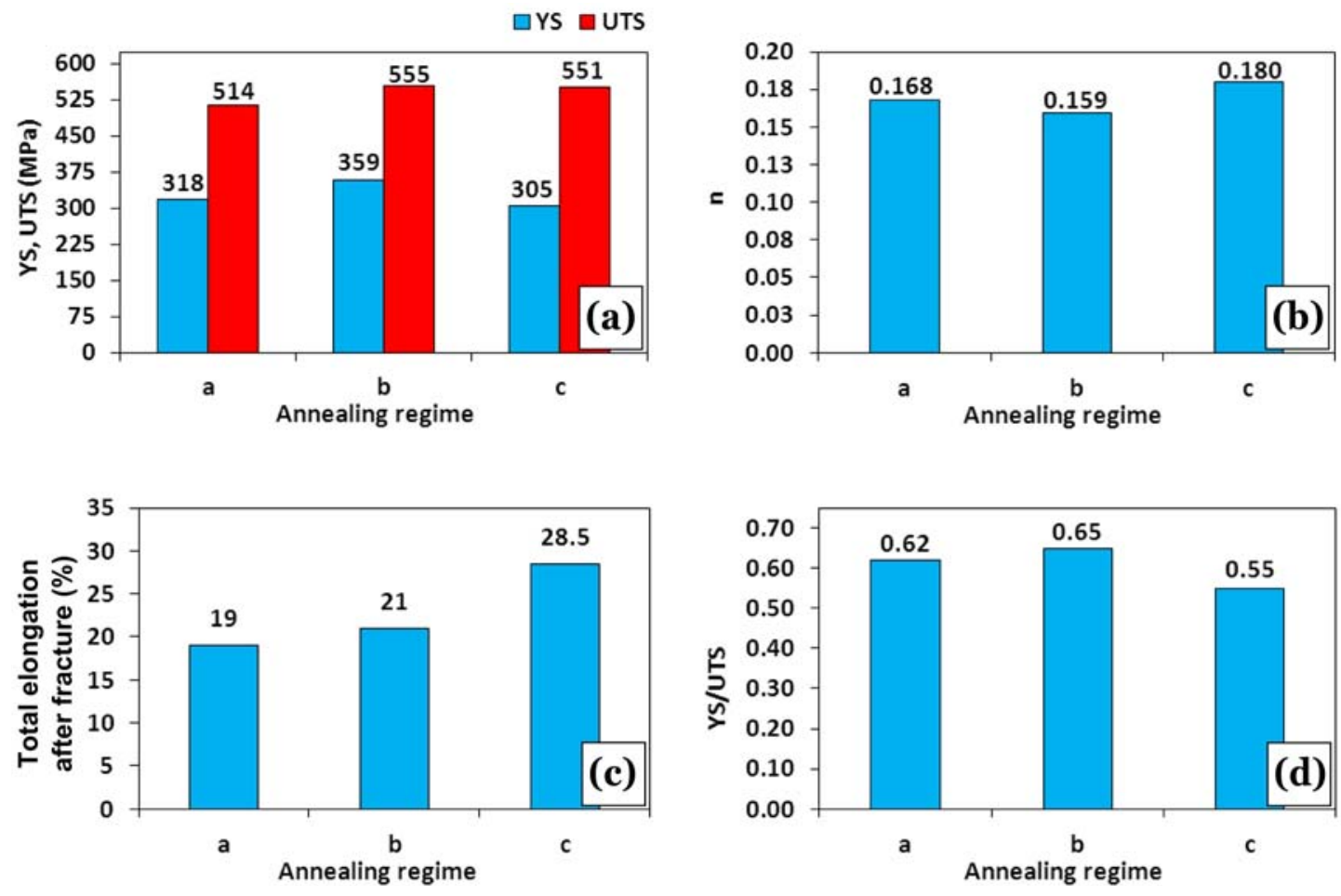

Fig. 3. Mechanical properties of DP steel grades.

ing a standard double-jet procedure. For the electropolishing process, the $\mathrm{CH}_{3} \mathrm{OH}: \mathrm{HClO}_{4}$ electrolyte in the ratio $9: 1$ was used. The polishing process was performed in the temperature range from -35 to $-25^{\circ} \mathrm{C}$ at $18 \mathrm{~V}$.

For hardness determination of individual phases, the nanoindentation measurements were performed. The Nanoindenter G200 with the Berkovich tip was used. All annealing regimes were investigated and 25 measurements for each phase per regime were done. The hardness $\left(H_{\mathrm{IT}}\right)$ measurements of ferritic grains were performed by the maximum loading force $F_{\max }$ $=19.62 \mathrm{mN}$. For hardness measurements of austenitic and martensitic grains, the maximum loading force of $F_{\max }=0.981 \mathrm{mN}$ was used. When relating the size of austenitic and martensitic grains in comparison to ferritic grains, the lower loading force needs to be used to avoid the hardness imprint distortion by surrounding ferritic grains [14].

\section{Results and discussion}

Related to the varying annealing regimes, the values of yield stress were changed, the maximum value was measured for annealing regime $b$. The value of yield stress for annealing regime $\mathrm{b}$ (heating into austenite region $\left(920^{\circ} \mathrm{C}\right)$ ) reached $359 \mathrm{MPa}$ and for annealing regime c (heating into austenite region $\left.\left(920^{\circ} \mathrm{C}\right)\right)$ and subsequent cooling into intercritical region $\left(780^{\circ} \mathrm{C}\right)$ decreased to $305 \mathrm{MPa}$. The values of the ultimate tensile stress behaved differently. The value of the ultimate tensile stress for annealing regime $\mathrm{b}$ increased up to $555 \mathrm{MPa}$ and for annealing regime $\mathrm{c}$ the value was kept at $550 \mathrm{MPa}$. The elongation values showed the increasing tendency with the maximum level for annealing regime 3 when reached $28.5 \%$. The strain hardening exponent $n$ and the ratio YS/UTS reached the best values for the first (a) and the third (c) annealing in Fig. 3.

Figure 4 shows the microstructure of all studied annealing regimes. In the first (a) selected regime, the microstructure consists of the ferritic matrix, austenite and areas with an indication to be martensite. No typical martensite was observed in the microstructure. After the second (b) selected annealing regime the microstructure was formed by the ferritic matrix, austenite, and martensite. In this case the partly martensite grains, surrounded by austenite, were observed. After the third (c) annealing regime, the microstructure was also formed by the ferritic matrix, austenite, and martensite, as observed in case b. After the third annealing regime (c), the higher appearance of martensitic grains in comparison to regime b was observed.

The microstructure of a dual phase steel was documented by optical microscopy (OM). To obtain the colour contrast, two etchants were used - Nital and Klemm. The microstructure of DP steel for all annealing regimes (Fig. 5a-c) consists of the ferritic matrix (tones of a brown colour) and austenite (white colour). It seems, based on SEM observations, that in 

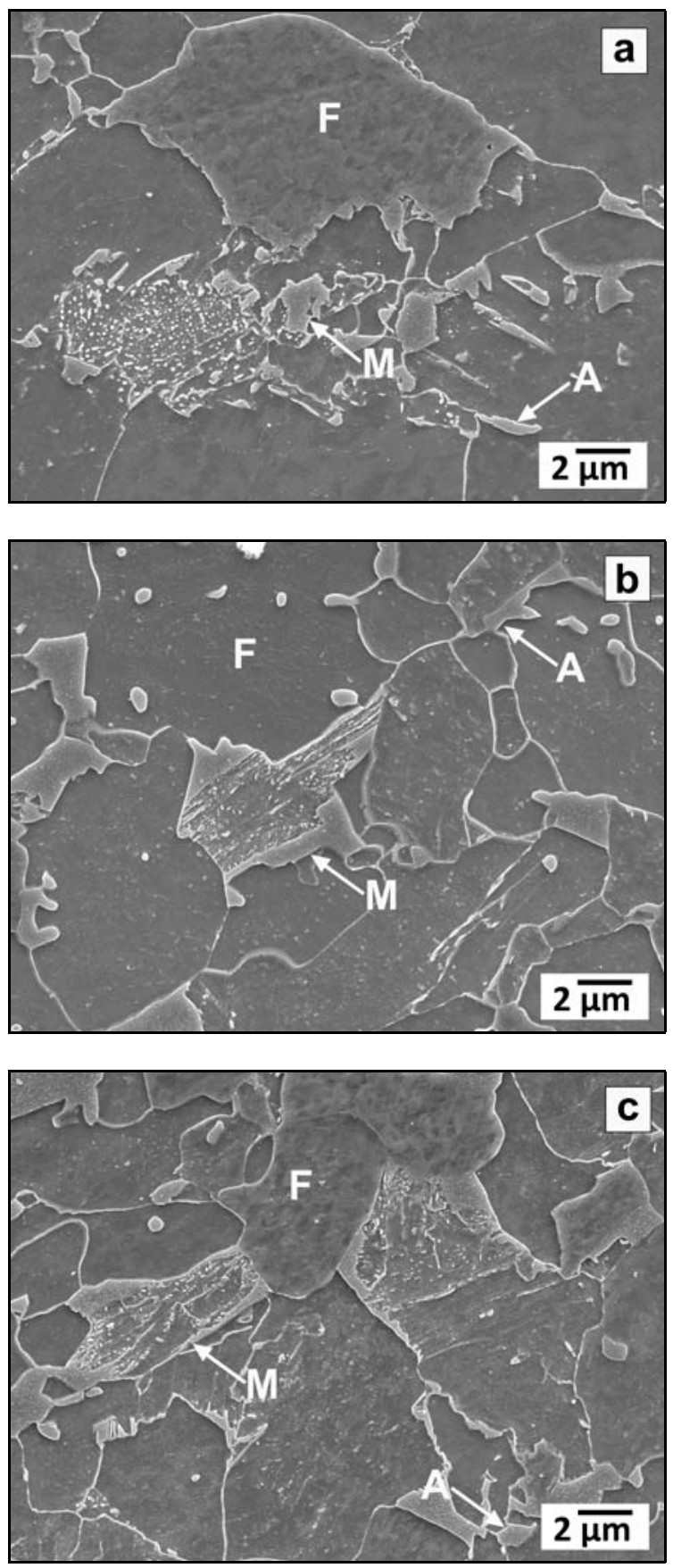

Fig. 4. Microstructure of DP steel: a) annealing regime $780{ }^{\circ} \mathrm{C}-495{ }^{\circ} \mathrm{C}$; b) annealing regime $920^{\circ} \mathrm{C}-495^{\circ} \mathrm{C}$; c) annealing regime $920^{\circ} \mathrm{C}-780^{\circ} \mathrm{C}-495^{\circ} \mathrm{C}$.

the case of white grains in SEM, these are brown in the middle on $\mathrm{OM}$, which means that the martensite is surrounded by austenite (regimes b and c).

When the martensitic grains were not surrounded by the austenite phase and the transformation was realized in the whole grain, no remarkable contrast between the ferrite and martensite by colour etching was achieved. For this reason, the specimen was etched
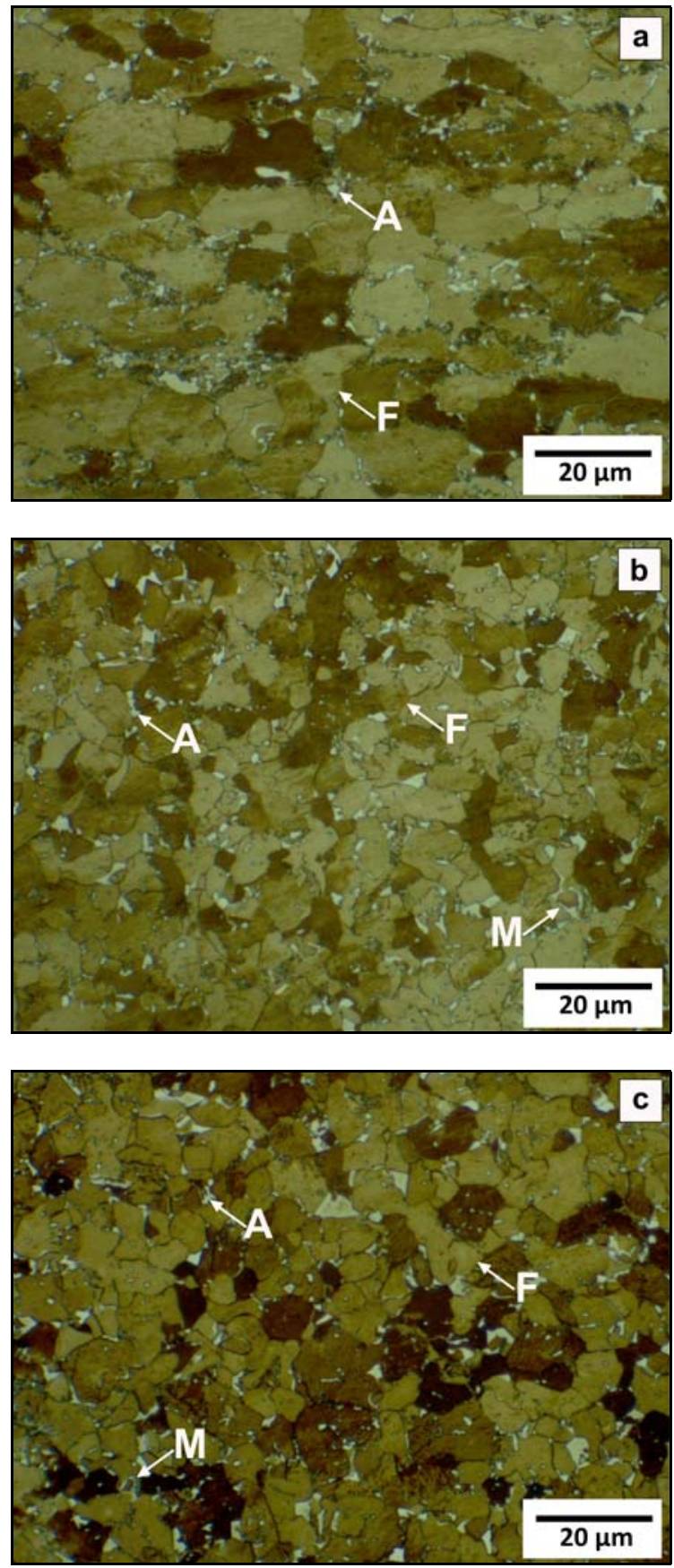

Fig. 5. Microstructure of DP steel: a) annealing regime $780^{\circ} \mathrm{C}-495{ }^{\circ} \mathrm{C}$; b) annealing regime $920^{\circ} \mathrm{C}-495^{\circ} \mathrm{C}$; c) annealing regime $920^{\circ} \mathrm{C}-780^{\circ} \mathrm{C}-495^{\circ} \mathrm{C}$.

by Nital, and SEM observations were performed. After that, the colour etching by the Klemm etchant was done and observations by OM were made. The results of martensitic grains' identification are shown in Fig. 6 where the black arrows show the identical martensitic grains.

Samples after two annealing regimes were subjected to TEM analysis: $780^{\circ} \mathrm{C}-495^{\circ} \mathrm{C}$ and $920^{\circ} \mathrm{C}$ 


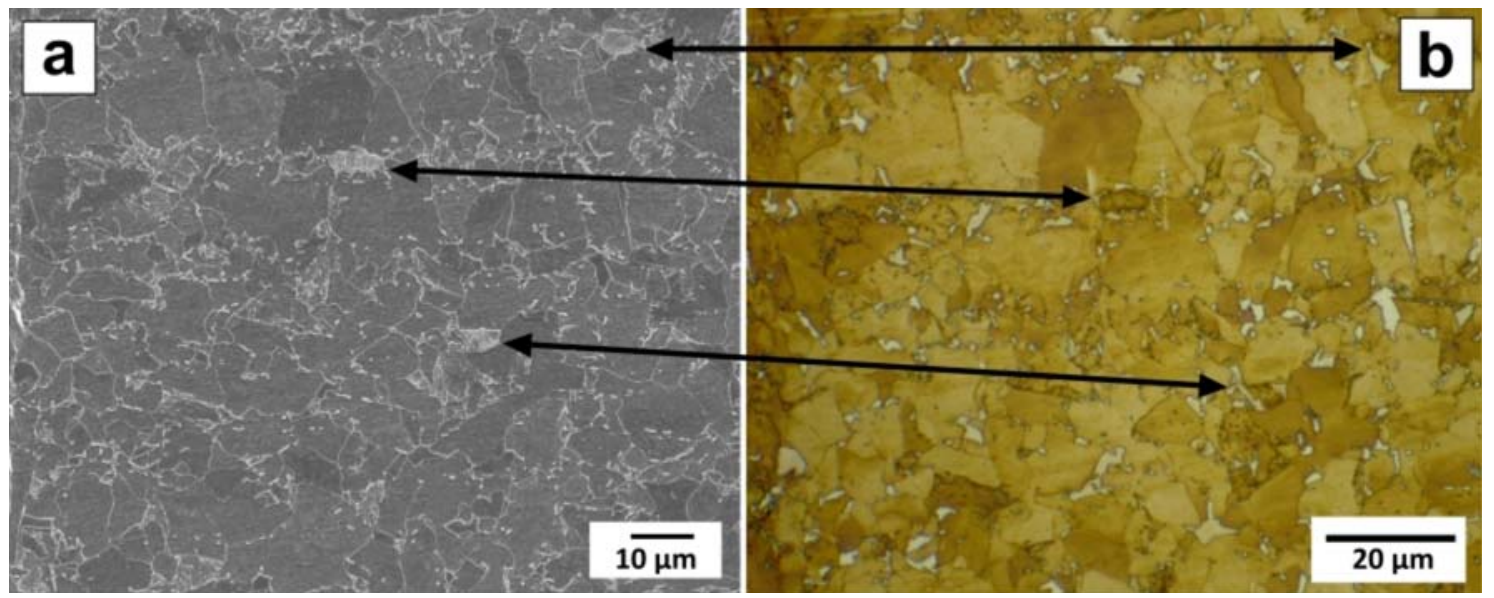

Fig. 6. Identification of martensitic phase.
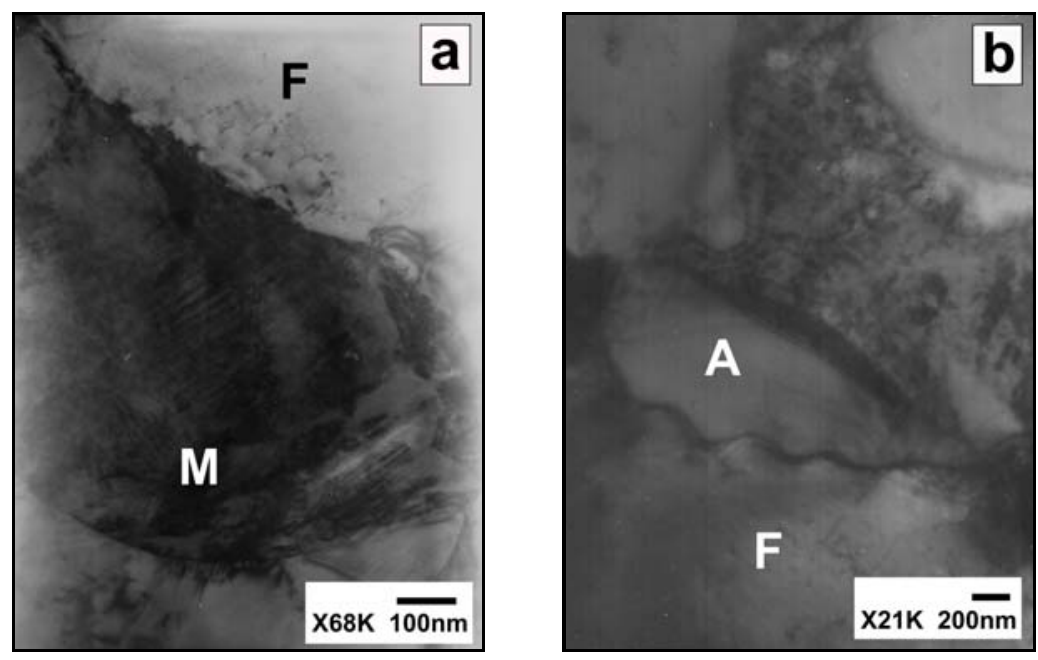

Fig. 7. Annealing regime $780^{\circ} \mathrm{C}-495^{\circ} \mathrm{C}$ : a) characteristic structure; b) austenitic grain.
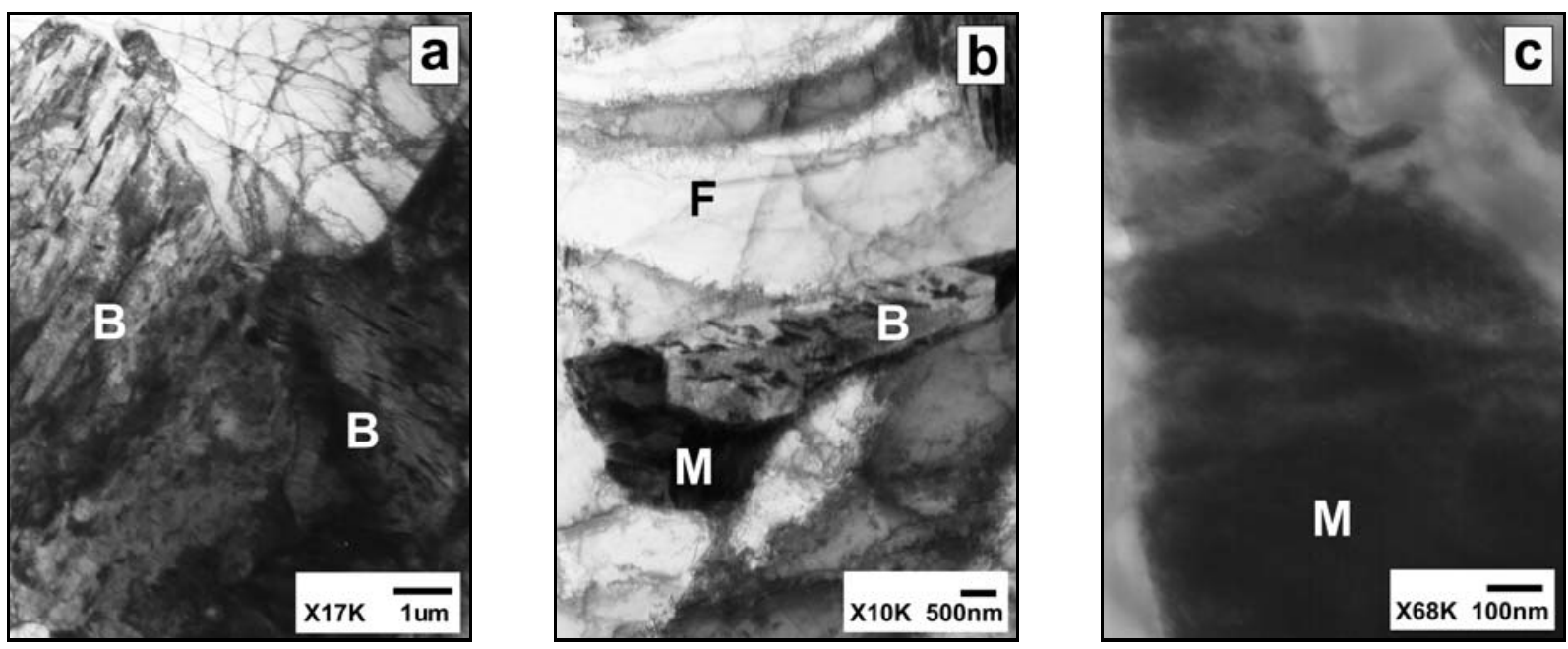

Fig. 8. Annealing regime $920^{\circ} \mathrm{C}-780^{\circ} \mathrm{C}-495^{\circ} \mathrm{C}$ : a) bainitic grain; b) partly transformed grain of bainite enclosed by martensite; c) detail of martensitic grain. 


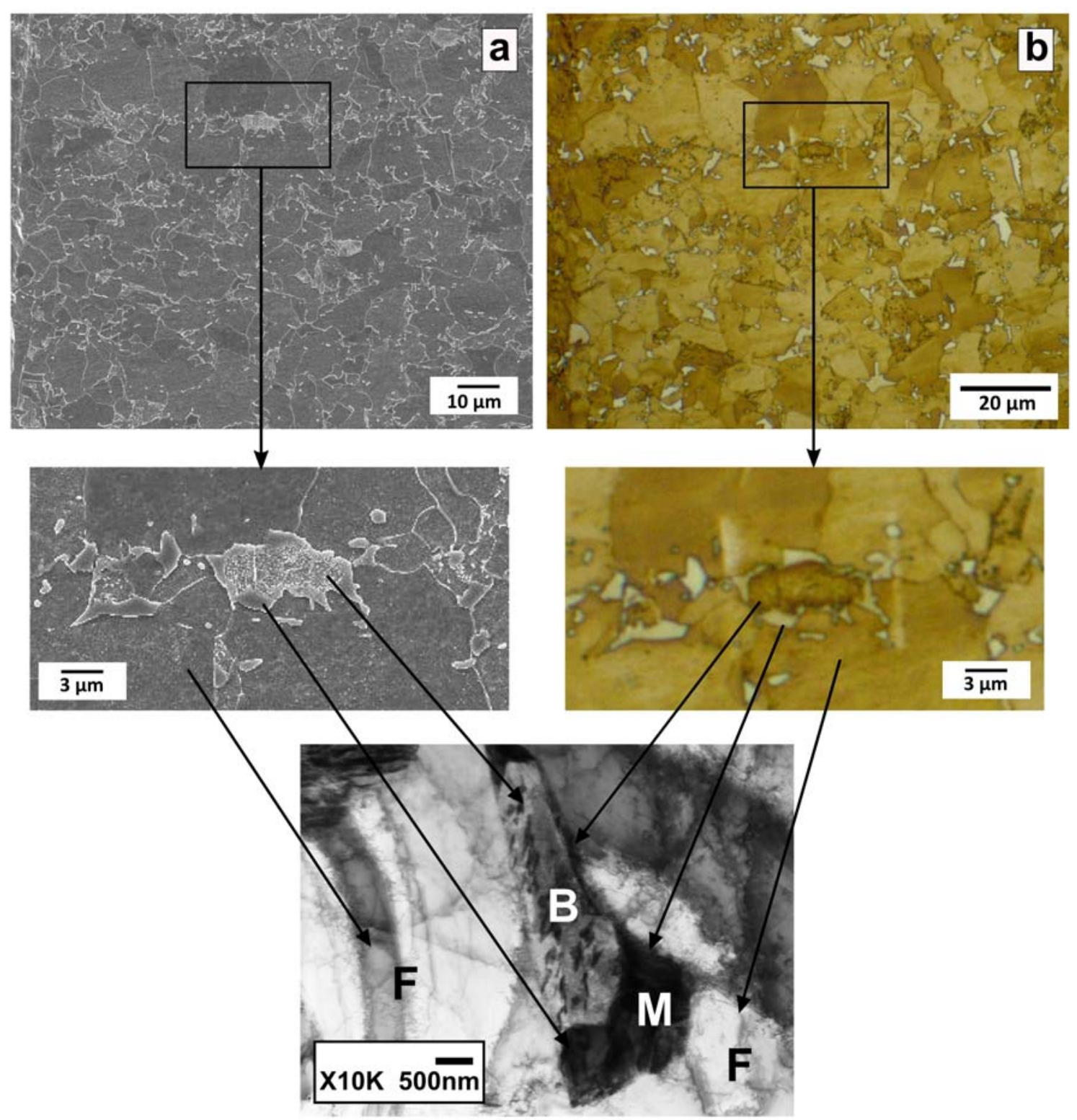

Fig. 9. Identification of individual phases and structures observed using the optical microscopy, SEM, and TEM.

$-780^{\circ} \mathrm{C}-495^{\circ} \mathrm{C}$. In case of the $780^{\circ} \mathrm{C}-495^{\circ} \mathrm{C}$ regime, the microstructure consisted of ferritic and martensitic grains. Figure 7a shows a detailed view of martensitic grain. Figure $7 \mathrm{~b}$ shows the grain of non-transformed austenite. However, the appearance of non-transformed austenite documented on Fig. 7b is sporadic, it is impossible to except the appearance of the higher amount of non-transformed austenite in the steel structure.

Figure 8 shows the final characteristic microstructure of the specimen after $920^{\circ} \mathrm{C}-780^{\circ} \mathrm{C}-495^{\circ} \mathrm{C}$ regime. The microstructure consisted of bainitic grains, Fig. 8a, and bainitic grains surrounded by martensitic phase, Fig. 8b. Figure $8 \mathrm{c}$ shows the detail of martensitic grain.

Figure 9 shows the correlation of individual phases and structures observed using OM, SEM, and TEM. Figure 9a shows the microstructure observed by SEM and Fig. 9b shows the same area observed by $\mathrm{OM}$ after colour etching. TEM was used to find the partly transformed grains that were observed by $\mathrm{OM}$ and SEM. Based on the SEM observations it was confirmed that these grains were martensitic. TEM observations showed that the partly transformed grains were bainite. A TEM observation also confirmed that the phase which totally or partly enclosed bainitic grains seems to be non-transformed austenite was in fact martensite. The evidence of that is the fragmentation into the smaller plates and the high dislocation density. In the case of colour etching (Klemm etchant) it can be said that the white grains represent martensite; bainite is brown 

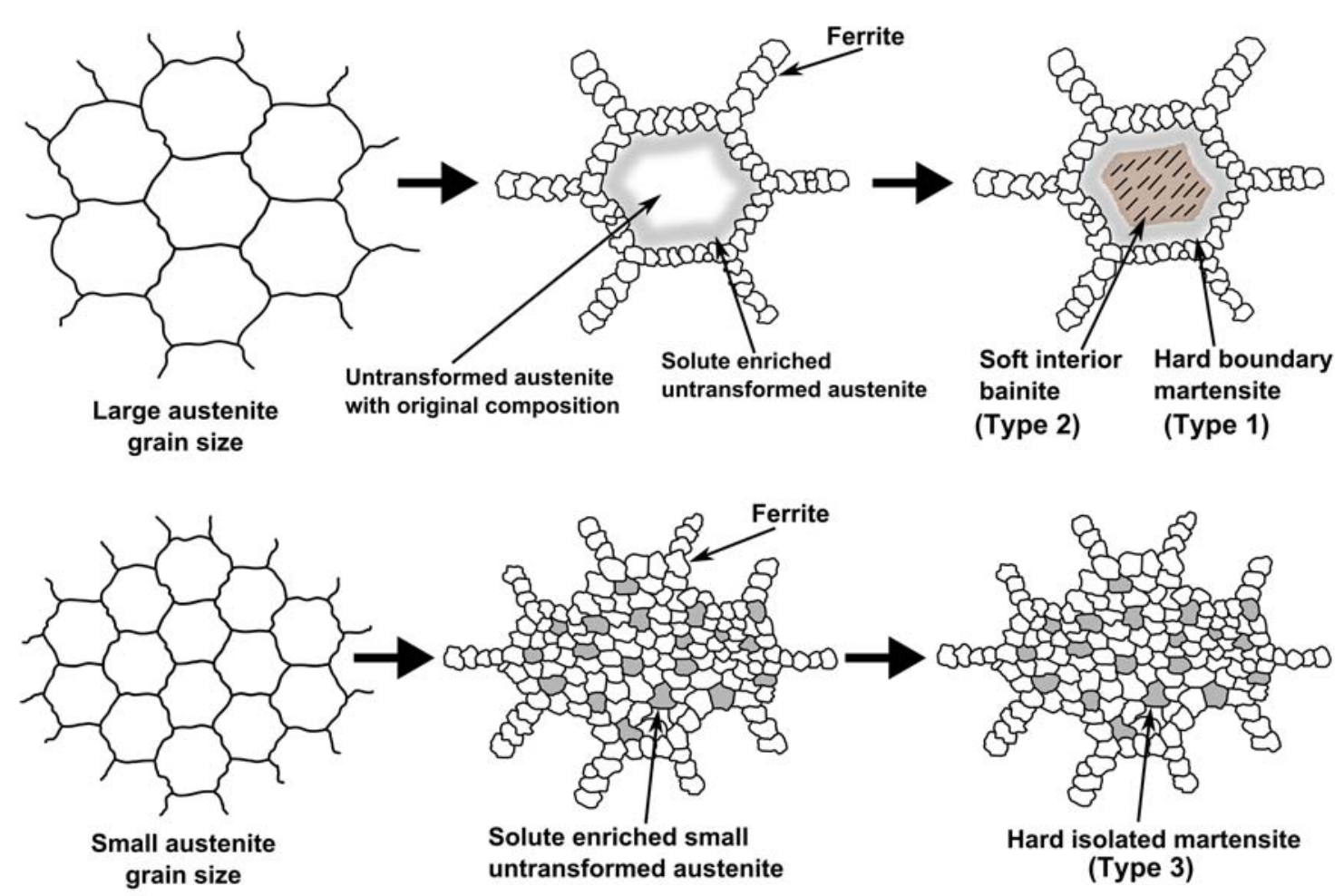

Fig. 10. Distribution of secondary phases in the microstructure during continuous cooling.

Table 2. Summary of the nanoindentation measurements

\begin{tabular}{cccc}
\hline Specimen & $H_{\text {IT ferrite }}(\mathrm{GPa})$ & $H_{\text {IT martensite }}(\mathrm{GPa})$ & $H_{\mathrm{IT} \text { mart./bainite }}(\mathrm{GPa})$ \\
\hline 1 & 2.2 & 4.2 & - \\
2 & 2.6 & 4.6 & 7.9 \\
3 & 2.5 & 4.9 & 7.3 \\
\hline
\end{tabular}

1. Annealing regime: $780^{\circ} \mathrm{C}-495^{\circ} \mathrm{C}$

2. Annealing regime: $920^{\circ} \mathrm{C}-495^{\circ} \mathrm{C}$

3. Annealing regime: $920^{\circ} \mathrm{C}-780^{\circ} \mathrm{C}-495^{\circ} \mathrm{C}$

and ferrite is also of a brown colour - bainite is darker.

Based on the observations that were performed, one should assume that on the origin of individual martensitic and bainitic grains that were accompanied by the martensite phase related to $920^{\circ} \mathrm{C}-$ $495^{\circ} \mathrm{C}$ and $920^{\circ} \mathrm{C}-780{ }^{\circ} \mathrm{C}-495^{\circ} \mathrm{C}$ regimes, there is the effect of the former size of the austenitic grain. Related to articles [8, 15, 16], during the cooling process, the diffusion of dissolved atoms of carbon to intercritical austenite from ferrite should support the bainite formation in these regions. When the diameter of the austenitic grain is not sufficiently small, the middle non-transformed part of the austenitic grain cannot effectively accumulate the dissolved carbon atoms and therefore the gradient of chemical composition into the centre of austenitic grain is formed. Due to the existence of the chemical composition gradient across the austenitic grain related to its diameter, different structure composition is created, namely: either isolated martensite grains or bainite accompanied by martensite, which bind the bainitic grain. When the accumulation of soluble carbon is high enough, the non-transformed austenite should become more stable and results in the formation of residual austenite. Figure 10 shows the scheme of microstructure evolution from the austenite during the continual cooling: 1) the hard martensite formed on the grain boundary; 2) the soft interior bainite and 3) the hard isolated martensite [15].

Table 2 summarizes the results of nanoindentation measurements $\left(H_{\mathrm{IT}}\right)$. Three different values of hardness were achieved. The hardness of ferrite was 2.2 to 2.6 GPa. Through simulation of annealing regime at 
temperature $495^{\circ} \mathrm{C}$ the martensite was tempered, and thus the lower values of hardness were obtained ( 4.2 to $4.9 \mathrm{GPa}$ ). The hardness of mixed grains martensite/bainite (bainite surrounded by martensite) in case of the annealing regime $920^{\circ} \mathrm{C}-495^{\circ} \mathrm{C}$ and $920^{\circ} \mathrm{C}-$ $780^{\circ} \mathrm{C}-495^{\circ} \mathrm{C}$ was 7.9 and $7.3 \mathrm{GPa}$, respectively.

\section{Summary}

The simulation process of the annealing regime which consisted of heating to austenite region $\left(920^{\circ} \mathrm{C}\right)$ resulted in a uniform structure. The heating into austenite region $\left(920^{\circ} \mathrm{C}\right)$ and subsequent cooling and holding in inter-critical region $\left(780^{\circ} \mathrm{C}\right)$ resulted in more stable mechanical properties with good strength and plastic characteristics of the studied dual phase steel.

The microstructure consists of the ferritic matrix, islands of martensite and mixed structure consisting of bainite and martensite.

TEM investigation expressly defined the individual phases of the studied steel after simulated conditions of annealing.

Nanoindentation measurements confirmed three different hardness values for three phases that appeared in the microstructure of DP steel.

\section{Acknowledgements}

We would like to acknowledge the Institute of Materials Research of the Slovak Academy of Sciences for the nanoindentation measurements that were carried out by using the Nano-indenter G200 from Agilent Company. This instrument was bought within the framework of the "New materials and technologies for energetics" project, ITMS 26220220061, financed through the European Regional Development Fund.

\section{References}

[1] International Iron and Steel Institute, Committee on Automotive Applications, Advanced High Strength Steel (AHSS), Application Guidelines 4.1 [online]. Available online at: http://www.worldautosteel.org
[2] Sun, S., Pugh, M.: Material Science \& Engineering A, 335, 2002, p. 298. doi:10.1016/S0921-5093(01)01942-6

[3] Rocha, R. O., Melo, E. V., Santos, D. B.: Materials Science Forum, 638-642, 2010, p. 3479. doi:10.4028/www.scientific.net/MSF.638-642.3479

[4] Papa Rao, M., Subramanya Sarma, V., Sankaran, S.: Materials Science and Engineering A, 568, 2013, p. 171. doi:10.1016/j.msea.2012.12.084

[5] Demir, B., Erdogan, M.: Journal of Materials Processing Technology, 208, 2008, p. 75. doi:10.1016/j.jmatprotec.2007.12.094

[6] Gao, L., Song, Q., Yuan, J.: Advanced Materials Research, 476-478, 2012, p. 241. doi:10.4028/www.scientific.net/AMR.476-478.241

[7] Meng, Q., Li, J., Wang, J., Zhang, Z., Zhang, L.: Materials and Design, 30, 2009, p. 2379. doi:10.1016/j.matdes.2008.10.026

[8] Asadi, M., De Cooman, B. Ch., Palkowski, H.: Materials Science and Engineering A, 538, 2012, p. 42. doi:10.1016/j.msea.2012.01.010

[9] Ma, C., Chen, D. L., Bhole, S. D., Boundreau, G., Lee, A., Biro, E.: Materials Science and Engineering A, 485, 2008, p. 334. doi:10.1016/j.msea.2007.08.010

[10] Li, G. B., Zhao, Z. Z., Tang, D.: Advanced Materials Research, 146-147, 2011, p. 1331. doi:10.4028/www.scientific.net/AMR.146-147.1331

[11] Zhao, Z., Jin, G., Niu, F., Tang, D., Zhao, A.: Transactions of Nonferrous Metals Society of China, 19, 2009, p. 563. doi:10.1016/S1003-6326(08)60313-1

[12] Jin, G., Yue, X., Zhao, M., Chen, S., Li, Q., Chang, G., Zhao, A.: Advanced Materials Research, 299-300, 2011 , p. 359. doi:10.4028/www.scientific.net/AMR.299-300.359

[13] DP-W and DP-K Dual-Phase Steels for the Manufacture of Complex High-Strength Structural Elements. Information Bulletin. Duisburg, Thyssen Krupp Steel AG 2009, p. 1.

[14] Delincé, M., Jacques, P. J., Pardoen, T.: Acta Materialia, 54, 2006, p. 3395 . doi:10.1016/j.actamat.2006.03.031

[15] Bhadeshia, H. K. D. H.: Bainite in Steels. London, Institute of Materials 1992.

[16] Park, S. H., Choo, W. Y.: In: Int. Symp. "Hot Workability of Steels and Light Alloys Composites". Eds.: McQueen, H. J., Konopleva, E. V., Ryan, N. D. Montreal, Canada, Canadian Institute of Mining, Metallurgy and Petroleum 1996, p. 493. 